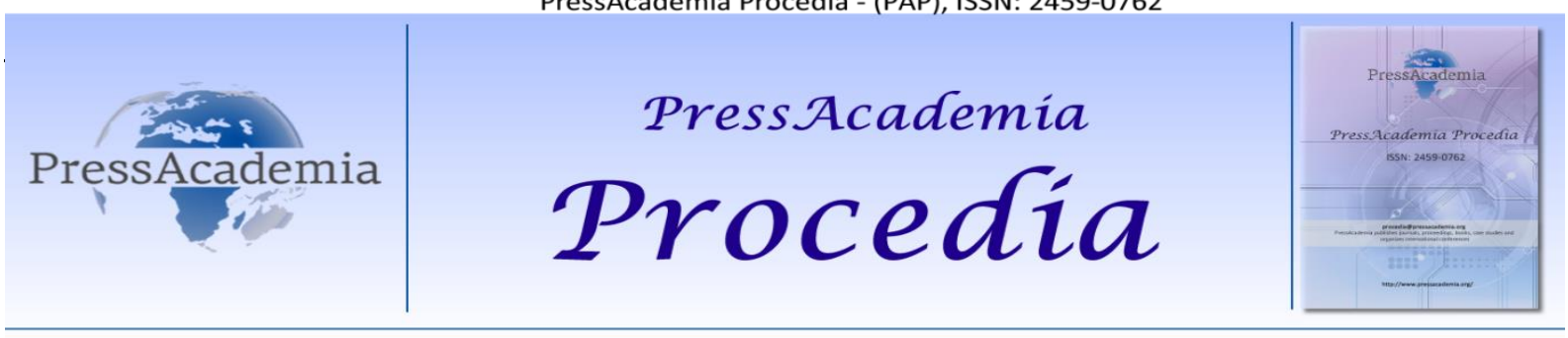

Global Business Research Congress (GBRC), May 24-25, 2017, Istanbul, Turkey.

\title{
THE PROVISIONS OF COLLECTIVE BARGAINING AGREEMENT APPLIED TO ALL THE EMPLOYEES
}

DOI: 10.17261/Pressacademia.2017.633

PAP- V.4-2017(1)-p.576-581

\section{Ercument Ozkaraca}

Marmara University. ercumentozkaraca@yahoo.com

\section{To cite this document}

Ozkaraca, E., (2017), The provisions of collective bargaining agreement applied to all the employees. PressAcademia Procedia (PAP), V.3, p.576-581.

Permanent link to this document: http://doi.org/10.17261/Pressacademia.2017.633

Copyright: Published by PressAcademia and limited licenced re-use rights only.

\begin{abstract}
Article 39 of Act no. 6356 on Trade Union and Collective Bargaining Agreements regulates which employees benefit from the rights arising from the agreement in the workplace or workplaces where the collective bargaining agreement is applied. Accordingly, the members of the employees' trade union, which is a party to the collective bargaining agreement, shall as principal benefit from that agreement. Article 25 of Act no. 6356 regulating the discrimination on the ground of trade union activities should also be taken into consideration in the matter of benefiting from the collective agreement. According to this article, difference of treatment between employees who are members of the trade union and those who are not is prohibited, as principal. However the provisions of the collective bargaining with respect of remuneration, bonuses, premiums and money-related social benefits shall be exceptions. This study aims to explain these provisions within the frame of the Court of Appeals.
\end{abstract}

Keywords: Collective bargaining agreement, employee, employer, discrimination, trade union activities

JEL Codes: K41, K31

\section{TOPLU iş SÖZLEŞMESININ TÜM IŞÇILERE UYGULANACAK HÜKÜMLERi}

\section{ÖZET}

Toplu iş sözleşmesinin uygulandığı işyeri ya da işyerlerinde sözleşme ile sağlanan haklardan hangi işçilerin yararlanabileceği 6356 sayııı Toplu iş Sözleșmesi Grev ve Lokavt Kanununun 39. maddesinde düzenlenmiştir. Buna göre toplu iş sözleşmesinden yararlanabilmek için kural olarak taraf iş̧̧i sendikasına üye olmak gerekir. Toplu iş sözleşmesinden yararlanma konusunda dikkate alınması gereken bir diğer düzenleme Kanunun sendikal ayııımcılık yasağını düzenleyen 25. maddesinde yer almaktadır. Buna göre, ücret, ikramiye, prim ve paraya ilişkin sosyal yardım konularındaki toplu iş sözleşmesi hükümleri saklı kalmak üzere sendikalı sendikasız işçi ayııımı yapılması yasaktır. Tebliğimizde konuya ilişkin Yargıtay içtihadı çerçevesinde bu hükümler incelenecektir.

Anahtar kelimeler: Toplu iş sözleşmesi, işçi, işveren, sendikal faaliyetler, ayrımcılık JEL Kodları: K41, K31

\section{GENEL OLARAK}

6356 sayılı Sendikalar ve Toplu İş Sözleşmesi Kanunu'nun toplu iş sözleşmesinden yararlanmaya ilişkin hükümleri incelendiğinde, toplu iş sözleşmesinden yararlanma yöntemlerinin taraf iş̧̧i sendikasına üye olmak veya dayanışma aidatı ödemek, Bakanlar Kurulu'nca teşmil uygulamasına gidilmesi ve taraf işçi sendikasının yazılı rızası suretiyle yararlanılması olduğu görülmektedir. Bunlardan teşmil ve yazılı rıza yöntemleri, uygulamada hemen hiç başvurulmayan oldukça istisnai yöntemlerdir. Dolayısyla işçiler genel olarak ya toplu iş sözleşmesine taraf işçi sendikasına üye olmak veya bu sendikaya dayanışma aidatı ödemek suretiyle toplu iş sözleşmesinden yararlanırlar. Bu koşulları yerine getirmeyenler ise toplu iş 
sözleşmesinden yararlanamazlar. Hatta üyelik ve dayanışma aidatı ödemek suretiyle yararlanmanın kapsamı dahi farklılık arz edebilmekte; sözleşmenin geriye etkili kılınması halinde dayanışma aidatı ödeyenler geriye etkili hükümlerden yararlanamamaktadırlar.

Ayrıca Kanunda, toplu iş sözleşmesinden yararlanma kavramından ne anlaşılması gerektiği de düzenlenmemiştir. Kanunun toplu iş sözleşmesinden yararlanmaya ilişkin hükümlerine bakıldığında, sözleşmenin tüm hükümlerinden sadece taraf sendikaya üye olan veya dayanışma aidatı ödeyen işçilerin yararlanabileceği sonucu çıkmaktadır. Bu durumda, taraf sendikaya üye olmayan ve dayanışma aidatı da ödemeyen işçilere toplu iş sözleşmesinde yer verilen hiçbir düzenlemenin uygulanmayacağı sonucuna varılabilecektir. Konu toplu iş sözleşmesi hükümlerinden sadece işçilere yarar sağlayan düzenlemeler açısından değil işçilere yükümlülükler getiren düzenlemeler açısından da önem taşımaktadır. Çeşitli hukuk sistemlerinde olduğu gibi (Alman Hukuku için bkz. Löwisch/Rieble, 2017: TVG § 3 Tarifgebundenheit, Rn. 34-35, Rn. 222; Franzen, 2017: TVG § 1 Inhalt und Form des Tarifvertrages, Rn. 45) hukukumuzda da bir işyerinde uygulanmakta olan toplu iş sözleşmesinin sadece sözleşmeye taraf işçi sendikasına üye olan veya dayanışma aidatı ödeyen işçilere uygulanacak hükümleri bulunduğu gibi, işyerinde çalışan tüm işçilere uygulanacak bazı hükümlerinin de bulunabileceği kabul edilmektedir. Başka bir deyişle, toplu iş sözleşmesinin bazı hükümleri taraf işçi sendikasına üye olma veya dayanışma aidatı ödeme koşullarını gerçekleştirmeyen işçilere de uygulanacaktır.

Hukukumuzda bu sonuca, toplu iş sözleşmesinden yararlanma kavramının sendikal nedenle ayırım yasağına ilişkin 25. madde ile birlikte değerlendirilmesi sonucu ulaşılmaktadır (Oğuzman, 1987: 68; Çelik \& Caniklioğlu \& Canbolat, 2016: 783784; Tuncay \& Savaş Kutsal: 2016 278; Şahlanan, 1992: 125-126; Narmanlıoğlu, 2016: 171-172; Sur, 2017: 339; Aktay \& Arıcı \&Senyen Kaplan, (2013): 534; Reisoğlu, 1986: 54, 149-150; Tuğ, 1996: 169-170; Ekmekçi, 1996: 134-135; Sümer, 2016 : 255-256; Akyiğit, 2015: 605-605; Özkaraca, 2014: 117-118; karş. Eyrenci, 1988: 8 vd. ). Söz konusu madde uyarınca, işveren, bir sendikaya üye olan işçilerle sendika üyesi olmayan işçiler veya ayrı sendikalara üye olan işçiler arasında, çalışma şartları veya çalıştırmaya son verilmesi bakımından herhangi bir ayrım yapamaz. Ücret, ikramiye, prim ve paraya ilişkin sosyal yardım konularında toplu iş sözleşmesi hükümleri saklıdır (m.25/2). Bu düzenlemeden çeşitli sonuçlar çıkarmak mümkündür : Illk olarak, işverenin toplu iş sözleşmesinden yararlanma koşullarına sahip olanlara, yani sözleşmeye taraf işçi sendikasına üye olan veya dayanışma aidatı ödeyenlere sözleşme ile getirilen parasal hakları sağlayıp, bu koşulları yerine getirmeyen işçilere sağlamaması hukuka uygun olup sendikal ayırımcılık olarak nitelendirilemeyecektir. Başka bir deyişle sözleşmenin parasal haklarından sadece üyelik veya dayanışma aidatı ödeme koşullarını yerine getiren işçiler yararlanabilecektir. Söz konusu düzenlemeden çıkarılabilecek olan ve konumuz açısından önem taşıyan diğer önemli sonuç ise, toplu iş sözleşmesinden yararlanma kavramının parasal konulara ilişkin hükümlerden yararlanma olarak anlaşıması gerektiği ve parasal hükümler dışındaki hükümlerin, yukarıda belirttiğimiz yararlanma koşullarını gerçekleştirmese de, işyerinde çalışan tüm işçilere uygulanması gerektiğidir (Çelik \& Caniklioğlu \& Canbolat, 2016: 784; Şahlanan, 1992: 125-126; Narmanlıoğlu, 2016: 172, 427; Sümer, 2016: 256; Ekmekçi, 1996: 136 vd.; Canbolat, 2002: 165-167; Özkaraca, 2016: 297). Aşağıda tüm işçilere uygulanacak toplu iş sözleşmesi hükümleri özellikle tartışma konusu olanlar esas alınarak incelenmeye çalışılacaktır.

\section{TÜM IŞÇILERE UYGULANACAK HÜKÜMLERIN KAPSAMI}

Teorik temelleri konusunda farklı görüşler bulunmakla birlikte (bu görüşler için bkz. Eyrenci, 1988: 8vd.) öğretide toplu iş sözleşmesinin işyerinde çalışan tüm işçilere uygulanacak hükümleri bulunduğu konusunda görüş birliği söz konusudur. Ancak konunun teorik temelleri hakkında değişik görüşler bulunduğu gibi toplu iş sözleşmelerinde yer verilen hükümlerden hangilerinin sadece yararlanma koşullarını gerçekleştirenlere hangilerinin tüm işçilere uygulanacağı konusunda da farklı görüşler söz konusudur. Bizim de katıldığımız görüşe göre, toplu iş sözleşmesinin sendikalı sendikasız tüm işçilere uygulanacak hükümleri, işçilere servis sağlanması, yemek verilmesi, giriş çıkış kontrolleri, iş güvenliği, çalışma ve dinlenme süreleri gibi işyerinin çalışma düzenine ilişkin, işçilerin ortak çıkarlarını gözeten hükümlerle sınırlı olmayıp, parasal konulara ilişkin olanlar dışındaki tüm hükümleridir (Ekmekçi, 1996: 141-142; Özkaraca, 2014: 118-119). Gerçekten, 6356 sayılı Kanun $\mathrm{m} .25 / 2$ 'de işverenin bir sendikaya üye olan iş̧̧ilerle sendika üyesi olmayan iş̧̧iler veya ayrı sendikalara üye olan iş̧̧iler arasında, çalışma şartları veya çalıştırmaya son verilmesi bakımından herhangi bir ayırım yapamayacağı öngörülmüş ve sadece ücret, ikramiye, prim ve paraya ilişkin sosyal yardım konularında toplu iş sözleşmesi hükümleri saklı tutulmuştur. Bu nedenle, paraya ilişkin olanlar dışında, çalışma şartları ve çalışmaya son verilmesine ilişkin tüm hükümler işyerindeki tüm iş̧̧ilere uygulanmalıdır (Ekmekçi, 1996: 141-142; Özkaraca, 2016: 298).

Bu konuda yöntem olarak, tüm işçilere uygulanacak nitelikteki hükümleri tek tek araştırmak yerine, istisna oluşturan "ücret, ikramiye, prim ve paraya ilişkin sosyal yardım" konularına ilişkin toplu iş sözleşmesi hükümlerinin neler olduğunun tespit edilerek bunların dışındaki tüm hükümlerin bütün işçilere uygulanacağının kabul edilmesinin daha pratik bir yöntem olduğu kanatindeyiz (Özkaraca, 2014: 119). Öğretide belirtildiği gibi, paraya ilişkin hükümlerle kastedilen parasal değeri bulunan tüm hükümler olmayıp, işçiye para verilmesine ilişkin hükümlerdir. Gerçekten, m.25/2'de sosyal yardımlardan sadece paraya ilişkin olanların istisna tutulmuş olması, istisnanın sadece nakit olarak yapılan ödemeleri kapsadığını, ayni yardımlardan tüm işçilerin yararlanabileceğini ortaya koymaktadır. (Ekmekçi, 1996: 142-143; Özkaraca, 2014: 119). 
Toplu iş sözleşmesinin parasal hükümleri ücret, ikramiye, prim, tatil ücretleri, izin harçlığı, fazla çalışma zammı, gece zammı, güçlük zammı, yakacak parası, bayram parası, çocuk parası, doğum parası, eğitim parası, yol parası, yemek parası gibi nakdi ödemelere ilişkin hükümlerdir (Ekmekçi, 1996: 143; Özkaraca, 2016: 298). Bu tür parasal hükümlerden sadece toplu iş sözleşmesine taraf işçi sendikasına üye olan veya dayanışma aidatı ödeyen iş̧̧iler yararlanabilirler. Toplu iş sözleşmesinin parasal konular dışındaki diğer çalışma koşullarına, örneğin çalışma süreleri, dinlenme zamanları, hafta tatili ve yıllık ücretli izin sürelerine, işçilere servis sağlanmasına, yemek verilmesine ilişkin hükümleri veya disiplin kurullarına, iş sözleşmelerine konulacak deneme süresine, çalıştırmaya son vermeye ilişkin hükümleri ise, sözleşmeden yararlanmaya ilişkin özel koşulları sağlayıp sağlamadığına bakılmaksızın tüm işçilere uygulanacaktır (Çelik \& Caniklioğlu \& Canbolat, 2016: 784; Sümer, 2016 : 256; Özkaraca, 2014: 119).

Uygulamada bazı işyerlerinde, yasal düzenlemeler esas alındığında iş güvencesi hatta i̧̧̇ Kanunu hükümleri uygulanmamasına rağmen toplu iş sözleşmeleri ile İş Kanunundaki düzenlemelere paralel düzenlemeler getirilmekte veya iş güvencesinden yararlanma koşulları hafifletilebilmekte, örneğin işyerinde çalışan işçilerin otuz iş̧̧i koşulu bulunmasa da iş güvencesinden yararlanacakları öngörülebilmektedir. İşte iş sözleşmesinin sona ermesine ilişkin normatif nitelikteki böyle bir düzenlemeden sadece sözleşmeye taraf işçi sendikasına üye olanlar veya dayanışma aidatı ödeyenler değil, sözleşmenin kapsamına giren diğer bütün iş̧̧iler de yararlanabilecektir.

Buna karşılık, bazı toplu iş sözleşmelerinde yer verilen kıdem tazminatının her hizmet yılı için otuz yerine kırkbeş gün üzerinden ödeneceğine ilişkin bir toplu iş sözleşmesi hükmü parasal nitelikte bir hüküm olduğundan, bu düzenlemeden sadece taraf sendikata üye olan veya dayanışma aidatı ödeyen işçiler yararlanabileceklerdir. Böyle bir hüküm de, sözleşmenin sona ermesine ilişkin olmakla birlikte, parasal nitelikteki bu hükümden işyerinde çalışan tüm işçilerin yararlanabileceği söylenemeyecektir (Özkaraca, 2016: 301).

\section{KONUYA ILIŞ̧KIN YARGITAY IÇTiHADININ DEĞERLENDIRILMESi}

Yargıtay da toplu iş sözleşmesi hükümlerinin kişi açısından kapsamını ve yararlanma koşullarını değerlendirirken m.25 hükmü ile bağlantı kurarak sonuca ulaşmakta ve genel olarak işyerinde çalışan tüm işçilere uygulanacak hükümlerin varlığını kabul etmektedir.

Yüksek Mahkeme örneğin 2016 yılında verdiği bir kararında, yukarıda belirttiğimiz iş güvencesinin kapsamını genişleten toplu iş sözleşmesi hükümleri açısından bu doğrultuda hüküm kurmuştur. Söz konusu karara göre, "...Davalı işyerinde sendika üyesi işçilerin çalıştığı ve yetkili sendika ile işveren arasında imzalanan Toplu iş̧ Sözleşmesi ile işyerinde işçi sayısı dikkate alınmaksızın, işçilerin iş güvencesi hükümlerinden yararlanmalarının sağlandığı uyuşmazlık dışıdır. Uyuşmazlık toplu iş sözleşmesine taraf sendika üyesi olmayan ve dayanışma aidatı da ödemeyen davacının toplu iş sözleşmesi ile getirilen iş güvencesi hükümlerinden yararlanıp yararlanmayacağı noktasında toplanmaktadır.

4857 sayılı iş Kanunu'nun 18. Maddesinde iş güvencesinden yararlanma koşullarından biri olan otuz ve daha fazla işçi bulunma koşulunu işçi lehine toplu veya bireysel iş sözleşmeleri ile düzenlenebileceği, bir başka anlatımla otuz işçi bulunma şartının daha az iş̧̧i sayısına (örneğin yirmi ve daha fazla iş̧̧i bulunma) indirilebileceği kabul edilmektedir. Kısaca bu düzenleme nisbi emredici olup işçi lehine iş güvencesi kapsamı genişletilebilir... Ayrıca Toplu iş̧ Sözleşmesi ile işçi lehine getirilecek bu düzenlemeden sendika üyesi işçiler yanında üye olmayan işçiler de 6356 sayılı Sendikalar ve Toplu iş̧ Sözleşmesi Kanunu'nun 25. maddesi uyarınca yararlanır. Zira anılan hükme göre "iş̧eren, bir sendikaya üye olan işçilerle sendika üyesi olmayan işçiler veya ayrı sendikalara üye olan işçiler arasında, çalışma şartları veya çalıştırmaya son verilmesi bakımından herhangi bir ayrım yapamaz. Ücret, ikramiye, prim ve paraya ilişkin sosyal yardım konularında toplu iş sözleşmesi hükümleri saklıdır". Böylece, toplu iş sözleşmesi ile bu konularda üyeler yararına ayrım yapılabileceği ve sözleşmenin parasal hükümlerinden sadece üyelerin yararlanacağı açıktır. Buna karşılık, diğer çalışma koşullarına ve bu arada çalışma süresi, yıllık ücretli izin süreleri gibi hükümler ile çalıştırmaya son vermeye ilişkin toplu iş sözleşmesi hükümlerinin taraf sendika üyesi olsun ya da olmasın işyerindeki bütün işçilere uygulanması gerekir... İş güvencesi hükümleri çalışma koşulları ve çalıştırmaya son vermeye ilişkindir. Toplu iş sözleşmesi ile düzenlenmesi halinde, işyerinde sendika üyesi olsun veya olmasın tüm iş̧̧ilere uygulanması gerekir. Nitekim somut uyuşmazııkta, davalının davacının iş sözleşmesini feshederken fesih ile ilgili disiplin soruşturmasını sözleşme hükümlerine göre yaptığı ve sözleşme hükümlerini sendika üyesiolmayan işçiye de uyguladığı sabittir. $O$ halde davacı hakkında toplu iş sözleşme ile kabul edilen iş güvencesi hükümlerinin uygulanacağı davalı işverenin de kabulündedir.

Mahkemece fesih konusunda ispat yükü de dikkate alınarak işin esasına girilmeli, tarafların belirttikleri deliler toplanmalı, bir değerlendirmeye tabi tutulmalı ve sonucuna göre karar verilmelidir. Yazılı şekilde davacının iş güvencesi hükümlerinden yararlanmayacağı gerekçesi ile görevsizlik kararı verilmesi hatalıdır.", (Yarg. 9. HD, 14.6.2016, E. 2016/13363 K. 2016/14311, www.yargitay.gov.tr). Yükek Mahkeme, 2016 tarihli bu kararının dışında, aynı konuya ilişkin olarak 2014 yılında verdiği üç diğer kararında da aynı sonuca ulaşmıştır (Yarg. 9. HD, 4.12.2014, E. 2014/25001 K. 2014/36926, Yarg. 9. HD, 4.12.2014, E. 2014/25525 K. 2014/36930; Yarg. 9. HD, 4.12.2014, E. 2014/25000 K. 2014/36925, karar ve değerlendirilmesi için bkz. Özkaraca, 2016: 299-301). 
Görüldüğü gibi, bu kararda Yargıtay iş güvencesinin kapsamını genişleten bir toplu iş sözleşmesi hükmünün sendika üyesi olsun veya olmasın işyerinde çalışan tüm iş̧̧ilere ugulanacağını kabul etmiştir. Yüksek Mahkeme, bu sonuca varırken, “...sözleşmenin parasal hükümlerinden sadece üyelerin yararlanacağı açıktır. Buna karşılık, diğer çalışma koşullarına ve bu arada çalışma süresi, yıllık ücretli izin süreleri gibi hükümler ile çalıştırmaya son vermeye ilişkin toplu iş sözleşmesi hükümlerinin taraf sendika üyesi olsun ya da olmasın işyerindeki bütün işçilere uygulanması gerekir..." ifadelerine yer vermiştir. Kararda kullanılan bu ifadelerden, çalışma sürelerini azaltan veya yıllık ücretli izin sürelerini artıran toplu iş sözleşmesi hükümlerinin de iş güvencesi ilişkin hükümler gibi tüm işçilere uygulanacağı sonucu çıkmaktadır. Aynı ifadeler yukarıda belirtilen diğer üç kararda da kullanılmıştır.

Oysa Yargıtay 9. Hukuk Dairesi daha önceki kararlarında aksi sonuca vararak toplu iş sözleşmesi ile öngörülen yıllık ücretli izin sürelerinden yararlanma konusundaki uyuşmazlıklarda, toplu iş sözleşmesinden yararlanma koşullarının gerçekleşip gerçekleşmediğinin araştırılması gerektiği yönünde kararlar vermiştir. Örneğin, 2006 tarihli bir kararda, “...Dosyaya sendika aidat fişi celbedilmeden... yıllık izin süresini de yine Tis'ne göre hesaplayan bilirkişi raporuna itibar edilerek anılan alacakların kabulüne karar verilmesi yerinde değildir" ifadeleri kullanılmıştır. (Yarg. 9. HD, 12.10.2006, E. 2006/5939 K. 2006/26945).

Yine 2014 yılında verilen başka bir kararda da Yargıtay 9. Hukuk Dairesi, yıllık ücretli izin süresinin toplu iş sözleşmesine göre hesaplanıp hesaplanmayacağının yararlanma koşullarının gerçekleşmesine göre değerlendirileceğinii kabul etmiştir (Yarg. 9. HD, 17.02.2014, E. 2012/998 K. 2014/4734, www.kazanci.com). Her ne kadar karara konu uyuşmazlıklar iş güvencesine ilişkin olup doğrudan yıllık ücretli izin sürelerine ilişkin olmasa da, yukarıda yer verdiğimiz 4.12.2014 ve 14.6.2016 tarihli kararlarda aksi yönde ifadelere yer veren 9. Hukuk Dairesi, konuya ilişkin görüşünü değiştirmiş görünmektedir.

Buna karşlık 22. Hukuk Dairesi, aksi görüşte olup toplu iş sözleşmelerinde yer verilen yıllık ücretli izin sürelerinin uzunluğuna ilişkin hükümlerden ancak taraf işçi sendikasına üyelik veya dayanışma aidatı ödemek koşullarını gerçekleştiren işçilerin yararlanabileceği, başka bir deyişle bu hükümlerinişyerinde çalışan tüm iş̧̧ilere uygulanmayacağı yönünde kararlar vermektedir (Yarg. 22. HD, 16.04.2014, E. 2013/8747 K. 2014/8347, www.yargitay.gov.tr). Öğretide de, Yargıtay 22. Hukuk Dairesi'nin içtihadı yönünde görüşler dile getirilmektedir (Şahlanan, Genel Görüşme, Değerlendirme 2014, 365; Eyrenci 1988: 9, 10).

Yargıtay 22. Hukuk Dairesi yakın bir zamanda 2017 yılında verdiği bir kararında da, “...Somut olayda, davacının 26.03.200728.04.2014 tarihleri arasında davalı işyerinde çalışması sonrası iş sözleşmesini emeklilik nedeniyle feshettiği ve çalıştığı sürece hak edipte kendisine kullandırılmadığını ileri sürdüğü yılık ücretli izin alacağının tahsilini talep ettiği, buna karşı davalı tarafın davacının 2011 yılı sonrası çalışmalarının toplu iş sözleşmesi hükümlerine göre değerlendirilebileceğini savunduğu, yapılan yargılama sonunda mahkemece alınan bilirkişi raporu doğrultusunda davacının yıllık ücretli izin alacağı işe girdiği tarihten itibaren sendikalı olup toplu iş sözleşmesinden faydalandığı kabulü ile toplam 103 gün... üzerinden hesaplandığı anlaşılmıştır.

Davacının işyerinde yürürlükte olan toplu iş sözleşmesine taraf sendikaya 19.01.2011 tarihinde üye olduğu ve dosya içerisinde yalnızca 01.12.2012-30.11.2014 arası geçerli 3. Dönem Toplu İ̧̧ Sözleşmesinin bulunduğu anlaşıımıştır. Mahkemece öncelikle davacının sendikaya üye olduğu tarih dikkate alınarak işyerinde yürürlükte bulunan toplu iş sözleşmesi dosya arasına alınarak toplu iş sözleşmesinin yürürlükte olduğu dönemde yıllıücretli izin hakkına ilişkin düzenlemeye göre yıllık ücretli izin hakkı belirlenmelidir. Davacının sendikalı olmadığı 19.01.2011 öncesi döneme dair yıllık ücretli izin hakkı ise İş Kanunu hükümlerine göre tespit edilmelidir. Yanılgılı değerlendirmeye dayalı olarak davacının tüm hizmet süresince sendikalı olduğu ve Toplu İş Sözleşmesinin ilgili 57. maddesi uyarınca yıllık 16 gün ücretli izin hakkı bulunduğunun kabulüne göre karar verilmesi hatalı olup, bozmayı gerektirmiştir..." ifadelerine yer verilmiştir.

Görüldüğü gibi, Yargıtay'ın iki dairesi arasında bu konuda görüş farklılığı söz konusu olup bu konuda içtihat birliğinin sağlanması gerekmektedir. Kanaatimizce bu konudaki yıllık ücretli izin süresine ilişkin hükümlerin işyerindeki tüm işçilere uygulanacağı yönünde olmalıdır. Bu konuda yıllık izin sürelerinin sonucu itibariyla parasal bir nitelik taşıdığı, izni fiilen kullanan işçilerin daha uzun bir süre çalışmadan ücret elde ettikleri, fiilen kullanmayan işçilerinse iş sözleşmeleri sona erdiğinde artırılmış izin sürelerinin ücretini son ücretleri üzerinden aldıkları, bu şekilde parasal sonuçları bulunan bu tür hükümlerden sadece toplu iş sözleşmesinden yararlanma koşullarını gerçekleştiren işçilerin yararlanması gerektiği ileri sürülebilir (Bu konuda bkz. Şahlanan, Genel Görüşme, Değerlendirme 2014, 365).

Bize göre ise, öğretide ve Yargıtay kararlarında, toplu iş sözleşmesine taraf iş̧̧i sendikasına üye olsun olmasın işyerinde çalışan tüm işçilere uygulanacağı kabul edilen diğer pek çok düzenleme de sonucu itibariyle parasal nitelik taşımaktadır. Örneğin, toplu iş sözleşmesi ile sağlanan servis ya da yemek yardımından yararlanan işçi de bu şekilde yemek yemek veya ulaşım için sarf edeceği bedeli harcamayarak parasal bir menfaat elde etmektedir (Özkaraca, 2016: 367).

Bunun gibi, toplu iş sözleşmesi ile haftalık çalışma süresinin 45 saatten 35 saate düşürüldüğü ve 35-45 saat arası yapılacak fazla sürelerle çalışmaların ücretlerinin \% 75 zamlı olarak ödeneceğinin kararlaştırıldığı bir olayda, tüm işçilerin haftalık çalışma süresi 35 saate indirilmiş olacaktır. Işçiler böylece 45 yerine 35 saat yani daha az süre çalışmalarına rağmen aynı 
ücreti elde edeceklerinden düzenlemenin parasal etkisi bulunmaktadır. Ancak böyle bir durumda, taraf iş̧̧i sendikasına üye olmayan ve dayanışma aidatı ödemeyen bir iş̧̧i fazla sürelerle çalışma yaptığında, sözleşmede öngörülen \% 75 zamlı ücreti talep edemeyecektir. Bireysel iş sözleşmesinde de ayrı bir kararlaştırma olmadığı sürece fazla sürelerle çalışmalar için saat başı \% 25 zamlı ücrete hak kazanacaktır (Özkaraca, 2014: 120).

İşte yıllık ücretli izin sürelerinin parasal nitelik taşıması da bu şekilde anlaşılmalı ve toplu iş sözleşmesi kapsamındaki tüm işçilerin izin sürelerinden yararlanabileceği kabul edilmelidir. Örneğin, yıllık ücretli izin süreleri toplu iş sözleşmesi ile kanundaki süreler ikişer gün artırılarak belirlendiğinde, sözleşme kapsamındaki tüm işçiler bu artırılmış süreler kadar izin hakkına sahip olacaklardır (Çelik \& Caniklioğlu \& Canbolat, 2016: 784; Reisoğlu, 1986: 149-150; Sümer, 2016: 256; Özkaraca, 2016: 302; Kar, Genel Görüşme, Değerlendirme 2014, 365;). Buna karşılık söz konusu aynı toplu iş sözleşmesinde izin harçlığı öngörülmüşse, taraf sendikaya üye olmayan ve dayanışma aidatı ödemeyen işçiler bu harçlıktan yararlanamayacaklardır. Bu kişiler izinlerini kullanmadan önce kendilerine konuya ilişkin genel esaslara göre hesaplanacak izin ücretleri peşin olarak ödenecek veya avans olarak verilecektir (İ̧̧K m.57/1). Yıllık izinlerini kullanmadan işten ayrılmaları durumunda da temel prensiplere uygun olarak toplu iş sözleşmesi ile artırılan süreler de dahil olmak üzere, kullanamadıkları izinlerin karşılığını son ücretleri üzerinden talep edebileceklerdir (İşK m.59/1). Yıllık ücretli izin sürelerinin artırılmasına ilişkin düzenleme doğrudan para verilmesine ilişkin bir hüküm değildir (Özkaraca, 2014: 120). Çeşitli mülahazalarla 6356 sayılı Kanun m.25/2'de yer alan pozitif düzenleme göz ardı edilmemelidir.

\section{KAPSAM DIŞI PERSONELIN DURUMU}

Uygulamada yapılan toplu iş sözleşmelerinde işyerinde müdür, şef gibi unvanlara sahip işçilerin hatta bütün büro personelinin sözleşmenin kapsamı dışında olduğu kararlaştııılabilmektedir. Kapsam dışı personel uygulaması Yargıtay içtihadında geçerli sayılmakta ve bu kişilerin toplu iş sözleşmesine taraf işçi sendikasına üye olsa dahi toplu iş sözleşmesinden yararlanamayacakları kabul edilmektedir (Bu uygulamanın hukuka uygun olup olmadığı hususundaki tartışmalar için bkz. Çelik \& Caniklioğlu \& Canbolat, 2016: 798-801).

Mevcut Yargıtay içtihadı esas alındığında, bu uygulama ile söz konusu kişilerin bütünüyle toplu iş sözleşmesinin kapsamı dışına çıkarılarak bireysel iş sözleşmesi alanına terk edilmesi karşısında, kapsam dışı personel 6356 sayılı Kanun m.25/2'ye dayanarak doğrudan para verilmesine ilişkin olanlar gibi bunların dışındaki toplu iş sözleşmesi hükümlerinin de kendilerine uygulanmasını talep edemeyecektir (Özkaraca, 2016: 305).,

\section{TOPLU iş SÖZLEŞMESININ GERIYE ETKILI YÜRÜRLÜĞE KONULMASI HALINDE TÜM IŞ̧ÇiLERE UYGULANACAK HÜKÜMLERIN DURUMU}

Toplu iş sözleşmesinin yapılması sürecinde yaşanan gecikmeler nedeniyle toplu iş sözleşmesi tarafları sözleşmenin yürürlük başlangıcını imza tarihinden daha önceki bir tarih olarak kararlaştırabilmektedirler. Ülkemiz uygulamasında toplu iş sözleşmeleri yaygın bir şekilde geriye etkili olarak yürürlüğe konulmaktadır. Bir toplu iş sözleşmesi hükmünün geriye etkili olarak yürürlüğe konulabilmesi için onunla getirilen yükümlülüğün ifa edileblir nitelikte olması gerekir. Geriye etkili kılınan bir toplu iş sözleşmesinden yararlanma koşulları 6356 sayılı Kanun m.39 hükmünde düzenlenmiştir. Buna göre toplu iş sözleşmesinin imza tarihinde taraf işçi sendikasına üye olanlar geriye etkili kılınan hükümlerden yararlanabilirken, imza tarihinden sonra üye olanların veya dayanışma aidatı ödeyerek toplu iş sözleşmesinden yararlananların geriye etkili kılınan hükümlerden yararlanmaları mümkün değildir. Ancak buradaki yararlanma kavramının da açıklığa kavuşturulması gerekir.

Toplu iş sözleşmesinin yürürlük başlangıcının geriye götürüldüğü durumlarda, işyerinde çalışan tüm işçilere uygulanacak nitelikte olan hükümlerden ifa edilebilir nitelikte olanlar da tarafların iradelerine göre geriye etkili kılınabilecektir (Özkaraca, 2014: 121). Örneğin, yukarıda verdiğimiz örnekteki gibi, toplu iş sözleşmesi ile haftalık çalışma süresinin 45 saatten 35 saate düşürülmesine ilişkin hükümler, işçinin iş görme edimini yerine getirme yükümlülüğünden geriye etkili olarak belirli bir ölçüde muaf tutulması, başka bir deyişle aradaki süre kadar fazla sürelerle çalışma yaptığının kabul edilmesi suretiyle geçerli sayılabilecek; bu çalışmanın karşılığı da işçiye zamlı ücret veya serbest zaman verilmek suretiyle sağlanabilecektir (Özkaraca, 2014: 121). Şüphesiz buradaki zamlı ücret yararlanmaya ilişkin özel koşulları gerçekleştirmeyen işçiler açısından toplu iş sözleşmesine göre belirlenmeyecektir. Öte yandan, bir hükmün tüm işçilere uygulanabilecek nitelikte olması, yürürlük başlangıcının geriye götürülebilirliği için yeterli olmayıp, geriye götürülebilirlik konusunda genel kurallar geçerlidir.

Kanaatimizce, yürürlük başlangıcı geriye götürülen bir toplu iş sözleşmesinin tüm iş̧̧ilere uygulanacak nitelikteki hükümlerinden geriye etkisi kabul edilenlerden, yürürlük başlangıcı ile imza tarihi arasında işyerinde çalışan sendikalısendikasız tüm işçiler yararlanacaktır. Kanunun, işverenin bir sendikaya üye olan işçilerle sendika üyesi olmayan işçiler veya ayrı sendikalara üye olan işçiler arasında, çalışma şartları veya çalıştırmaya son verilmesi bakımından herhangi bir ayırım yapamayacağına ve sadece ücret, ikramiye, prim ve paraya ilişkin sosyal yardım konularında toplu iş sözleşmesi ile farklı düzenleme getirilebileceğine ilişkin m.25/2 hükmü karşısında farklı bir sonucu varılması olanaklı değildir. Bu işçiler, söz konusu hükümlerden ileriye yönelik olarak taraf sendikaya üye olmaya ve dayanışma aidatı ödemeye gerek olmaksızın yararlanabildikleri gibi, geriye yönelik olarak da üye olmalarına gerek olmaksızın yararlanabileceklerdir. Zira, bu kişilerin 
geleceğe yönelik yararlanmaları açısından da herhangi bir mali külfete katlanma yükümlülüğü söz konusu değildir. Aynı sonucun geriye etki dönemi açısından da kabulüne bir engel bulunmamaktadır (Özkaraca, 2014: 122-123).

\section{SONUÇ}

Toplu iş sözleşmesinden yararlanma konusunda 6356 sayılı Kanun m.39 ile m.25 hükümleri birlikte değerlendirilmelidir. Kanuna göre, işveren ücret, ikramiye, prim ve paraya ilişkin sosyal yardım konuları dışındaki toplu iş sözleşmesi hükümleri saklı kalmak kaydıyla, işçiler arasında çalışma koşulları veya çalıştırmaya son verilmesi bakımından sendikal statülerine göre ayırım yapamaz. Dolayısıyla toplu iş sözleşmesinin parasal hükümleri dışındaki tüm hükümleri sözleşme kapsamındaki işyerlerinde çalışan tüm işçilere uygulanacaktır. Burada kriter, hükmün para verilmesine ilişkin bir hüküm olup olmadığıdır. Toplu iş sözleşmesi taraflarının bu tür hükümleri geriye etkili kılmaları durumunda da, o dönemde işyerinde çalışan işçiler başka bir koşul aranmaksızın bu hükümlerden yararlanacaklardır.

\section{KAYNAKLAR}

Aktay N./Arıcı K./Senyen Kaplan, E.T. (2013), İş Hukuku, 6. Baskı, Ankara.

Akyiğit, E. (2015), Toplu İş Hukuku El Kitabı, Ankara.

Canbolat, T. (2002), Toplu İş Sözleşmesinden Yararlanamayacak İşçiler, Kamu İş, C. 6, S. 4

Çelik N./Caniklioğlu N./Canbolat T. (2016), İş Hukuku Dersleri, 29. Baskı, İstanbul.

Ekmekçi, Ö. (1996), Toplu İş Sözleşmesiyle Düzenleme Yetkisi, İstanbul

Eyrenci, Ö. (1988), Toplu İş Sözleşmesinin İşyerinde Çalışan Bütün İşçilere Uygulanacak Hükümleri”, Kamu-İş, C.1, S.4.

Franzen, M. (2017), in Erfurter Kommentar zum Arbeitsrecht, 17. Auflage, München.

Löwisch, M./Rieble, V. (2017), Tarifvertragsgesetz, 4. Auflage, München.

Narmanlıoğlu, Ü. (2016), İş Hukuku II, Toplu İş İlişkileri, 3. Baskı, İstanbul.

Oğuzman, K. (1987), Hukuki Yönden İş̧̧i-İşveren İlişkileri, 4. Bası, İstanbul

Özkaraca, E. (2014), Toplu İş Sözleşmesinin Geriye Etkisi, İstanbul

Özkaraca, E. (2016), Toplu İş İlişkileri Açısından Yargıtayın 2014 Yılı Kararlarının Değerlendirilmesi, Yargıtayın İş Hukuku ve Sosyal Güvenlik Hukukuna İlişkin 2014 Yılı Kararlarının Değerlendirilmesi, Ankara.

Reisoğlu, S. (1986), 2822 Sayılı Toplu İş Sözleşmesi Grev ve Lokavt Kanunu Şerhi, Ankara.

Sur, M. (2017), İş Hukuku Toplu i̇lişkiler, 6. Bası, Ankara.

Sümer, H.H. (2016), İş Hukuku, 21. Baskı, Ankara.

Şahlanan, F. (1992) Toplu İ̧̧ Sözleşmesi, İstanbul.

Tuğ, A. (1996), Toplu iş̧ Sözleşmesi, Ankara.

Tuncay, A.C./Savaş Kutsal, F.B., (2016), Toplu İş Hukuku, 5. Bası, İstanbul. 